\title{
IMPLEMENTASI UPAH MINIMUM KABUPATEN BOYOLALI TERHADAP PEKERJA/BURUH PADA USAHA KONVEKSI BERDASARKAN UNDANG-UNDANG RI NOMOR 13 TAHUN 2003 TENTANG KETENAGAKERJAAN
}

\author{
Lucia Rachmawati \\ Email: lunar.rahma@gmail.com \\ Mahasiswa Program Magister Ilmu Hukum Fakultas Hukum \\ Isharyanto \\ Email: masis_uns@yahoo.com \\ Djoko Wahju Winarno \\ Email: wahjuwinarnodjoko@gmail.com \\ Dosen Fakultas Hukum UNS
}

\begin{abstract}
Wages are the rights of laborers/workers received in return from the employer or employers for a job and/or services that have been or will be implemented. Minimum standards are used by employers to provide wages to laborers/workers are minimum wage. This article aim to know Implementation of Minimum Wages Boyolali Regency to laborers/workers on the Convection Based on the Law Republic of Indonesia Number 13 Year 2003 about Employement. This research is a socilogical/empirical legal that is eksplanatif (explain). Research locations are some convections in Teras and sorounding in Boyolali Regancy, and The office for cooperatives and labor Boyolali Regancy. Based on this research obtained the results of that Implementation of Minimum Wages Boyolali Regency to laborers/workers on the Convection Based on the Law Republic of Indonesia Number 13 Year 2003 about Employement not run optimally.
\end{abstract}

Key words: Minimum Wage; Laborers/Workers; Employement Inspection, Welfare

\begin{abstract}
Abstrak
Upah merupakan hak pekerja/buruh yang diterima sebagai imbalan dari pengusaha atau pemberi kerja atas suatu pekerjaan dan/atau jasa yang telah atau akan dilaksanakan. Standar minimum yang digunakan pengusaha untuk memberikan upah kepada pekerja/buruh adalah upah minimum. Artikel ini bertujuan untuk mengetahui implementasi Upah Minimum Kabupaten Boyolali terhadap pekerja/buruh pada usaha konveksi berdasarkan Undang-Undang RI No. 13 Tahun 2003 tentang Ketenagakerjaan. Penelitian ini adalah penelitian hukum sosiologis/penelitiam hukum empiris yang bersifat eksplanatif (menerangkan). Lokasi penelitian adalah beberapa usaha konveksi di Teras dan sekitarnya di Kabupaten Boyolali, dan Dinas Koperasi dan Tenaga Kerja Kabupaten Boyolali. Berdasarkan penelitian ini diperoleh hasil bahwa Implementasi Upah Minimum Kabupaten Boyolali Terhadap Pekerja/Buruh Pada Usaha Konveksi Berdasarkan Undang-Undang RI Nomor 13 Tahun 2003 Tentang Ketenagakerjaan belum berjalan secara optimal.
\end{abstract}

Kata kunci: Upah Minimum; Pekerja/Buruh; Pengawasan Ketenagakerjaan, Kesejahteraan 


\section{A. Pendahuluan}

Upah merupakan hak pekerja/buruh yang diterima dan dinyatakan dalam bentuk uang sebagai imbalan dari pengusaha atau pemberi kerja kepada pekerja/buruh yang ditetapkan dan dibayarkan menurut suatu perjanjian kerja, kesepakatan, atau peraturan perundang-undangan, termasuk tunjangan bagi pekerja/buruh dan keluarganya atas suatu pekerjaan dan/atau jasa yang telah atau akan dilaksanakan. (Husni, 2014: 234) Upah sering kali merupakan satu-satunya bekal bagi pekerja/buruh dan keluarganya untuk melangsungkan kehidupannya. Keberlangsungan hidup pekerja/buruh tergantung pada upah yang mereka terima selama mereka bekerja.

Jaminan kehidupan yang layak yang berkaitan dengan pekerja/buruh diatur secara khusus dalam Undang-undang Ketenagakerjaan salah satunya tentang penghasilan yang layak. Pasal 88 ayat (1) Undang-Undang RI No. 13 Tahun 2003 tentang Ketenagakerjaan menjelasakan bahwa setiap pekerja/buruh berhak memperoleh penghasilan yang memenuhi penghidupan yang layak bagi kemanusiaan. Untuk melindungi hak pekerja/buruh tersebut maka pemerintah menetapkan kebijakan-kebijakan pengupahan yang tertuang dalam pasal 88 ayat (3) Undang-Undang RI No. 13 Tahun 2003 tentang Ketenagakerjaan salah satunya adalah kebijakan upah minimum.

Kebijakan upah minimum dipandang sebagai instrumen kebijakan yang sesuai untuk mencapai kepantasan dalam hubungan kerja, dan memiliki beberapa tujuan. (Shamad, 1992: 83) Kebijakan upah minimum yang ditetapkan oleh pemerintah digunakan sebagai jaring pengaman agar upah yang diterima pekerja/buruh tidak jatuh pada tingkat yang paling rendah.

Baru-baru ini pemerintah mengeluarkan peraturan terkait dengan pengupahan yaitu
Peraturan Pemerintah RI No. 78 Tahun 2015 tentang Pengupahan yang menggantikan Peraturan Pemerintah RI No. 8 Tahun 1981 tentang Perlindungan Upah. Menurut Peraturan Pemerintah tersebut upah minimum adalah upah bulanan terendah yang terdiri atas upah tanpa tunjangan; atau upah pokok termasuk tunjangan tetap. Upah minimum ditetapkan oleh Gubernur sebagai jaring pengaman agar upah yang diterima pekerja/ buruh tidak jatuh pada tingkat yang paling rendah. Formula perhitungan upah minimum yang ditetapkan oleh Gubernur juga berubah dengan dikeluarkannya Peraturan Pemerintah tersebut. Perubahan tersebut terdapat pada kenaikan upah minimum dimana setiap tahunnya menjadi baku yaitu dari peresentase kenaikan upah minimum adalah inflasi ditambah pertumbuhan ekonomi. Dengan formula tersebut memastikan adanya kenaikan upah bagi pekerja/buruh setiap tahunnya dan memberikan kepastian mengenai besarnya kenaikan upah setiap tahunnya.

Terkait dengan Upah Minimum, salah satu provinsi yang menetapkan upah minimum dari 34 Provinsi di Indonesia adalah Provinsi Jawa Tengah. Gubernur Jawa Tengah menetapkan upah minimum untuk 35 kabupaten/kota salah satunya Kabupaten Boyolali. Kabupaten Boyolali berbatasan dengan Kabupaten Semarang dan Kabupaten Grobogan di utara; Kabupaten Sragen, Kabupaten Karanganyar, Kabupaten Sukoharjo dan Kota Surakarta (Solo) di timur; Kabupaten Klaten dan Daerah Istimewa Yogyakarta di Selatan; serta Kabupaten Magelang dan Kabupaten Semarang di barat. Kabupaten ini termasuk kawasan Solo Raya. Pada Kabupetan ini terdapat banyak perindustrian yang dapat menampung tenaga kerja yang potensial. Mayoritas industri yang berada di wilayah Boyolali adalah bergerak dalam bidang tekstil. Kawasan industri Boyolali dirancang untuk industri berbasis TPT terintegrasi, termasuk dilengkapi dengan infrastruktur yang memadai 
dan fasilitas pusat pelatihan dan inovasi. Kawasan ini difokuskan untuk industri tekstil (garmen) karena keterbatasan air. (Wikipedia, https://id.m.wikipedia.org/wiki/Kabupaten Boyolali, diakses pada 10 Oktober 2016, jam 20.10 WIB)

Industri tekstil (garmen) di Boyolali tidak hanya usaha-usaha formal tetapi juga terdapat usaha informal dimana banyak mempekerjakan pekerja/buruh untuk menjalankan usahanya. Usaha-usaha tekstil yang mendominasi di Kabupaten Boyolali khusunya di daerah Teras dan sekitarnya adalah usaha-usaha kecil dan menengah, seperti usaha konveksi. Usaha konveksi merupakan usaha yang mengolah barang setengah jadi menjadi barang jadi seperti kemeja, celana, dan lain-lain. Usaha konveksi sama dengan usaha garmen yaitu sama-sama merupakan usaha yang bergerak di bidang pembuatan barang jadi tekstil, yang membedakan adalah pada usaha konveksi dikelola oleh perorangan, dengan jumlah pegawai yang bekerja lebih sedikit dan mesin yang digunakan sangat terbatas, dalam pengerjaan suatu produk masih dalam skala kecil. Sedangkan usaha garmen bisanya berupa pabrik atau perusahaan dengan sistem pengelolaan yang lebih baik, produksi usaha garmen dalam skala besar sehingga dalam proses pengerjaan menggunakan pekerja lebih banyak. Walaupun pada usaha konveksi jumlah pekerja/buruh yang bekerja lebih sedikit dibandingkan pada usaha garmen, tetapi hak pekerja/buruh tersebut harus tetap terjamin khususnya mengenai upah.

Sejahtera menunjuk kepada kondisi manusia dimana orang-orangnya dalam keadaan makmur, keadaan sehat dan damai. Indikator kesejahteraan dapat dilihat dari 3 hal yaitu jumlah dan pemerataan pendapatan, pendidikan yang semakin mudah dijangkau, kualitas kesehatan yang semakin meningkat dan merata.
(Kompasiana, http://m.kompasiana.com/ icai/indikator-kesejahteraan, diakses pada 2 November 2016, jam 14.00 WIB)

Berdasarkan indikator tersebut, kesejahteraan dalam pengupahan didefinisikan bahwa semua kebutuhan minimum pekerja/ buruh dan keluarganya dapat terpenuhi secara layak. Setidaknya dengan terpenuhinya upah pekerja/buruh sesuai dengan upah minimum yang telah ditetapkan pemerintah dapat menyejahterakan pekerja/buruh dan keluarganya. Selanjutnya untuk dapat merealisasikan kesejahteraan bagi pekerja/ buruh dalam hal upah yang layak, maka kebijakan pengupahan yang telah ditetapkan pemerintah perlu untuk diimplementasikan.

Implementasi dipandang secara luas mempunyai makna pelaksanaan peraturan perundang-undang di mana berbagai aktor, organisasi, prosedur dan teknis bekerja bersama-sama untuk menjalankan kebijakan dalam upaya untuk meraih tujuan-tujuan kebijakan atau program-program.(Winarno, 2013: 147)

Berdasarkan paparan diatas, maka akan dibahas mengenai bagaimana Implementasi Upah Minimum Kabupaten Boyolali Terhadap Pekerja/Buruh Pada Usaha Konveksi Berdasarkan Undang-Undang RI Nomor 13 Tahun 2003 Tentang Ketenagakerjaan.

\section{B. Metode Penelitian}

Penelitian menurut David H Penny (dikutip dari Saebani, 2009: 12) adalah pemikiran yang sistematis mengenai berbagai jenis masalah yang pemecahannya memerlukan pengumpulan dan penafsiran fakta-fakta. Adapun metode penelitian yang digunakan oleh penulis dalam penelitian ini adalah sebagai berikut: Jenis penelitian ini adalah penelitian hukum sosiologis atau penelitian hukum empiris. Pada 
penelitian hukum yang sosiologis, hukum dikonsepkan sebagai pranata sosial yang secara rill dikaitkan dengan variabel-variabel sosial yang lain. (Amiruddin dan Asuikin, 2004: 133) Penelitian ini menurut sifatnya adalah penelitian eksplanatif (menerangkan). Penelitian eksplanatif bertujuan menguji hipotesis-hipotesis tentang ada tidaknya hubungan sebab akibat antara berbagai variabel yang diteliti. (Amiruddin dan Asuikin, 2004: 26) Lokasi yang dipilih adalah beberapa usaha konveksi di Teras Kabupaten Boyolali dan sekitarnya, dan Dinas Koperasi dan Tenaga Kerja (Dinkopnaker) Kabupaten Boyolali. Jenis data terdiri dari data primer dan data sekunder. Sumber data diperoleh dari sumber data primer maupun sumber data sekunder. Menurut Soerjono Soekanto (dikutip dari Amiruddin dan Asuikin, 2004: 67), penelitian lazimnya dikenal tiga jenis alat pengumpulan data, yaitu studi dokumen atau bahan pustaka, pengamatan atau obervasi, dan wawancara atau interview. Penelitian ini menggunakan beberapa cara untuk mengumpulkan data, yaitu: Wawancara (interview), Kuisioner, Studi Dokumen. Analisis data dengan cara kualitatif yaitu mengolah dan menganalisis data-data yang sistematik, teratur dan terstruktur dan mempunyai makna. Cara berpikir pada penelitian ini adalah berpikir Deduktif. Hasil dari produk berpikir deduktif menurut Saebani (2009: 111) dapat digunakan untuk menyususn hipotesis, yakni jawaban sementara yang kebenarannya masih perlu diuji atau dibuktikan melalui proses keilmuan selanjutnya.

\section{Hasil Penelitian dan Pembahasan}

Konsep negara kesejahteraan/kemakmuran, negara dituntut untuk memperluas tanggung jawabnya kepada masalah-masalah sosial ekonomi yang dihadapi oleh rakyat banyak, peran personal untuk menguasai hajat hidup rakyat banyak dihilangkan. (Muntoha, 2009 : 386) Indonesia menganut konsep negara kesejahteraan dimana negara sebagai pihak yang aktif berorientasi pada pemenuhan dan perwujudan kesejahteraan rakyat sesuai dengan prinsip welfare state. Sehingga pemerintah dituntut untuk aktif dalam kehidupan ekonomi sosial masyarakat, sebagai langkah untuk mewujudkan kesejahteraan umum, disamping menjaga ketertiban dan keamanan. Dalam hal pengupahan Pemerintah pun dituntut untuk menetapkan upah sesuai dengan penghidupan yang layak bagi pekerja/ buruh. Berdasarkan Pancasila sila ke lima yaitu "keadilan sosial bagi seluruh rakyat Indonesia" yang pada prinsipnya negara Indonesia didirikan untuk bersungguhsungguh memajukan kesejahteraan bagi seluruh rakyat Indonesia baik lahir maupun batin, setiap warga negara berhak untuk mendapatkan pekerjaan dan penghidupan yang layak, bermartabat dan berkeadilan bagi kemanusiaan, setiap warga negara dijamin untuk mendapatkan pendidikan, pekerjaan, dan penghidupan yang layak, bermartabat, dan berkeadilan.

Kebijakan pengupahan yang melindungi pekerja/buruh ditetapkan oleh Pemerintah salah satunya adalah kebijakan upah minimum. Kebijakan pemerintah yang telah diambil tersebut harus diimplementasikan. Menurut pendapat Ripley dan Franklin (dikutip dari Winarno, 2013:148) bahwa implementasi adalah apa yang terjadi setelah undang-undang ditetapkan yang memberikan otoritas program, kebijakan, keuntungan (benefit), atau suatu jenis keluaran yang nyata (tangible output). Istilah implementasi menunjuk pada sejumlah kegiatan yang mengikuti pernyataan maksud tentang tujuan-tujuan program dan hasil-hasil yang diinginkan oleh para pejabat pemerintah. Implementasi mencakup tindakan-tindakan (tanpa tindakan-tindakan) oleh berbagai aktor, khususnya pada birokrat, yang dimaksudkan untuk membuat program berjalan.

Upah Minimum yang berlaku di Boyolali tahun 2017 adalah UMK berdasarkan 
Keputusan Gubernur Jawa Tengah No. 560/50 Tahun 2016 tentang Upah Minimum pada 35 (tiga puluh lima) Kabupaten/Kota di Provinsi Jawa Tengah Tahun 2017 sebesar Rp. 1.519.289,- dan berlaku bagi semua pekerja/ buruh di seluruh wilayah Kabupaten Boyolali.

Upah minimum berlaku bagi pekerja atau buruh dengan tingkat paling rendah dengan masa kerja kurang dari 1 tahun. Bagi upah pekerja dengan masa kerja 1 tahun atau lebih ditetapkan sesuai dengan kesepakan pekerja dengan pengusaha. Kesepakatan antara pekerja atau buruh atau serikat pekerja atau buruh dengan pengusaha secara bipartit dengan menimbang produktifitas dan kemampuan perusahaan. (Endut A, http://www.jambur. com/ekonomi/20161121/3747/ini-umk-35kabupaten-kota-di-jawa-tengah-tahun-2017, diakses pada 4 April 2017, jam 11.42 WIB)

Upah Minimum Kabupaten Boyolali tersebut juga berlaku bagi usaha-usaha konveksi yang berada di wilayah Kabupaten Boyolali. Berdasarkan Peraturan Menteri Perindustrian Republik Indonesia No. 64/M-IND/PER/7/2011 tentang Jenis-Jenis Industri dalam Pembinaan Direktorat Jenderal dan Badan di Lingkungan Kementeriaan Perindustrian, Badan Pusat Statistik dan Undang-Undang RI No. 20 Tahun 2008 tentang Usaha Mikro, Kecil, dan Menengah bawah usaha konveksi dapat digolongkan menjadi usaha industri kecil atau usaha industri menengah. Berikut hasil dari penelitian yang penulis lakukan tentang implementasi UMK Boyolali terhadap pekerja/buruh di beberapa usaha konveksi di Kabupaten Boyolali berdasarkan Undang-Undang RI No. 13 Tahun 2003 tentang Ketenagakerjaan.

\section{Usaha Konveksi Pasifik Garment}

Hasil wawancara dengan Pengusaha dan Pekerja/Buruh pada Usaha Konveksi Pasifik Garment adalah bahwa usaha konveksi tersebut telah berdiri lebih dari 5 (lima) tahun yang lalu, beralamat di
Kragilan, Mojosongo, Boyolali dan telah memilik izin usaha dan telah terdaftar. Usaha konveksi tersebut merupakan usaha yang dimiliki oleh Ibu Heni Laraswati yang mempekerjakan 50 orang pekerja/ buruh. Jenis pekerjaan yang ada pada konveksi tersebut terdiri dari supervisor, asisten supervisor, operator sewing, helper, quality control. Pekerja/buruh bekerja selama 8 jam dalam satu hari dan 6 hari kerja selama satu minggu. Upah yang pekerja/buruh terima berbeda-beda berdasarkan keterampilan dan jabatan yang pekerja/buruh miliki. Sistem upah pada Pasifik Garment adalah bulanan. Upah untuk supervisor Rp. 3.000.000,per bulan, sedangkan asisten supervisor di bawah sedikit dari supervisor. Upah untuk pekerja/buruh yang bekerja pada bagian operator sewing, helper dan quality control adalah Rp. 1.530.000,- per bulan. Tiga belas (13) dari lima puluh (50) pekerja/buruh mengisi kuisioner dengan hasil upah pekerja/buruh pada Usaha Konveksi Pasifik Garment lebih dari UMK Boyolali yaitu sebesar Rp. 1.530.000,-.

Berdasarkan hasil kuisioner dan wawancara yang telah penulis lakukan bahwa pelaksanaan UMK Boyolali Tahun 2017 telah terlaksana pada Usaha konveksi Pasifik Garment berdasarkan Keputusan Gubernur Jawa Tengah No. 560/50 Tahun 2016 tentang Upah Minimum pada 35 (tiga puluh lima) Kabupaten/Kota di Provinsi Jawa Tengah Tahun 2017 untuk UMK Boyolali sebesar Rp. 1.519.289,-Usaha Konveksi Pasifik Garment telah memberikan upah diatas UMK Boyolali tahun 2017 yaitu sebesar Rp. 1.530.000,-.

\section{Usaha Konveksi CV Triabadi Apparel}

Hasil wawancara dengan Pengusaha dan Pekerja/Buruh pada Usaha Konveksi CV Triabadi Apparel adalah bahwa usaha 
konveksi tersebut baru berdiri pada bulan Juli 2016 lalu, beralamat di Desa Jatirejo, Sawit, Boyolali dan merupakan usaha informal yang belum terdaftar tetapi telah membuat akta pendirian perusahaan yang berencana akan mendaftar tahun 2017. Usaha konveksi tersebut merupakan usaha yang dimiliki oleh Bapak Indra Waskito dimana mempekerjakan 50 orang pekerja/ buruh. Jenis pekerjaan yang ada pada konveksi tersebut terdiri dari operator sewing, helper, quality control. Pekerja/ buruh yang berkerja pada CV Triabadi Apparel bekerja selama 8 jam dan 5 hari selama satu minggu. Upah yang pekerja/ buruh pada CV Triabadi Apparel berbedabeda berdasarkan keterampilan yang pekerja/buruh miliki. Sistem upah pada CV Triabadi Apparel adalah bulanan. Upah untuk pekerja/buruh yang bekerja pada bagian operator sewing adalah Rp. 1.430.000,- per bulan sedangkan untuk helper Rp. 990.000,- per bulan. Dua puluh empat (24) dari lima puluh (50) mengisi kuisioner bahwa pekerja/buruh Usaha Konveksi CV Triabadi Apparel belum mendapatkan upah sesuai dengan UMK Boyolali yaitu hanya sebesar Rp. 990.000,- sampai Rp. 1.430.000,-.

Berdasarkan hasil kuisioner dan wawancara yang telah penulis lakukan bahwa pelaksanaan UMK Boyolali Tahun 2017 belum dapat terlaksana pada Usaha Konveksi CV Triabadi Apparel berdasarkan Keputusan Gubernur Jawa Tengah No. 560/50 Tahun 2016 tentang Upah Minimum pada 35 (tiga puluh lima) Kabupaten/Kota di Provinsi Jawa Tengah Tahun 2017 untuk Upah Minimum Kabupaten Boyolali yang besar Rp. 1.519.289,--. Usaha Konveksi CV Triabadi Apparel memberikan upah dibawah UMK Boyolali tahun 2017 yaitu sebesar Rp. 990.000,- sampai Rp. 1.423.000,-.
Terkait dengan upah minimum, pengusaha yang belum mampu membayar upah pekerja/buruh sesuai dengan upah minimum yang telah ditetapkan maka dapat mengajukan penangguhan. Pada tanggal 29 September 2016, Mahkamah Konstitusi (MK) mengabulkan sebagian permohonan uji materiil pasal 90 ayat (2) Undang-Undang No. 13 Tahun 2003 tentang Ketenagakerjaan melalui Putusan No. 72/PUU-XIII/2015 yang dimohonkan aktivis buruh Sukarya dan Siti Nurrofiqoh, mahkamah konstitusi menghapus bagain frasa penjelasan pasal 90 ayat (2) UndangUndang No. 13 Tahun 2003 tentang Ketenagakerjaan. (Hukum Online.com, http://m. hukumonline.com/berita/baca/putusanmk-ini-kabar-baik-buat pekerja, diakses pada 23 Februari 2017, jam 21.03 WIB)

Amar putusan No. 72/PUUXIII/2015, penjelasan pasal 90 ayat (2) Undang-Undang No. 13 Tahun 2003 tentang Ketenagakerjaan sepanjang frasa "tetapi tidak wajib membayar pemenuhan ketentuan upah minimum yang berlaku pada waktu diberikan penangguhan" bertentangan dengan Undang-Undang Dasar Negara RI Tahun 1945 dan tidak mempunyai kekuatan hukum tetap. Berarti bahwa mahkamah konstitusi memberikan penegasan selisih kekurangan pembayaran upah minimum tetap wajib dibayarkan oleh pengusaha selama masa penangguhan. Penangguhan upah tidak serta merta menghilangkan kewajiban pengusaha untuk membayar selisih upah minimum selama penangguhan. Pengusaha wajib membayar selisih upah minimum setelah selesai waktu penangguhan karena selisih upah minimum merupakan utang pengusaha yang wajib dibayar kepada pekerja/buruh.

Terkait dengan pengawasan ketenagakerjaan Undang-Undang RI No. 23 Tahun 2014 yang telah diubah dengan 
Undang-Undang No. 2 Tahun 2015 tentang Pemerintahan Daerah urusan pengawasan ketenagakerjaan adalah urusan wajib dan bersifat konkuren antara Pemerintah Pusat dan Pemerintah Daerah. Pemerintah Pusat berwenang menetapkan sistem pengawasan dan mengelola petugas pengawas ketenagakerjaa, sedangkan Pemerintah Provinsi berwenang menyelenggarakan pengawasan ketenagakerjaan.

Pada 2 Oktober 2016 pengawasan ketenagakerjaan sudah berada di tingkat provinsi, tidak lagi di tingkat kabupaten/ kota. (Pos Sore Aktual dan Kasual, http:// possore.com/2016/05/09/sentralisasipengawasan-ketenagakerjaan-mulaiberlaku-oktober-2016/, diakses pada 4 April 2017, jam 11.30 WIB) Semua tugas pengawasan ketenagakerjaan yang ada disetiap kabupaten/kota seluruh Indonesia statusnya beralih ke provinsi. Pemerintah Kabupaten Boyolali cq Dinas Koperasi dan Tenaga Kerja Bidang Hubungan Industrial dan Jaminan Sosial Tenaga Kerja (dahulu bernama Dinas Sosial Tenaga Kerja dan Transmigrasi Kabupaten Boyolali) sekarang tidak lagi berwenang untuk melakukan pengawasan ketenagakerjaan (dalam hal penegakan). Pemerintah Kabupaten Boyolali cq Dinas Koperasi dan Tenaga Kerja Bidang Hubungan Industrial dan Jaminan Sosial Tenaga Kerja hanya melaksankan tugas pelayanan teknis dan administrasi dibidang hubungan industrial dan penerapan norma perlindungan Jaminan Sosial Tenaga Kerja.

Berdasarkan hasil wawancara dengan Kepala Bidang Hubungan Industrial dan Jaminan Sosial Tenaga Kerja Dinkopnaker Kabupaten Boyolali bahwa dengan dialihkannya tugas pengawasan dari kabupaten/kota kepada provinsi, maka tugas Dinkopnaker Kabupaten Boyolali cq Bidang Hubungan Industrial dan Jaminan Sosial Tenaga Kerja hanya memberikan pembinaan, penyuluhan, menjaga hubungan industrial, menyiapkan pengupahan dan mediasi menurut peraturan perundang-undangan ketenagakerjaan dan tidak bersifat menegakkan tetapi lebih kepada menjaga hubungan Tripatrit (pemerintah, pengusaha, pekerja/buruh).

Terkait dengan pelaksanaan upah minimum yang telah ditetapkan oleh pemerintah, Dinkopnaker Kabupaten Boyolali cq Bidang Hubungan Industrial dan Jaminan Sosial Tenaga Kerja bertugas untuk melakukan Pemantauan atau Monitoring UMK Boyolali setiap awal bulan yaitu setelah gaji bulan pertama diterima pekerja/buruh atau setiap akhir bulan Januari atau awal bulan Februari. Tujuan dilakukannya Monitoring UMK Boyolali adalah untuk:

a. Mengetahui kepatuhan pengusaha di Kabupaten Boyolali dalam melaksanakan pembayaran UMK Boyolali sesuai ketentuan peraturan perundang-undangan yang berlaku.

b. Meningkatkan pembinaan dan pengawasan serta mencegah pelanggaran terhadap pemenuhan UMK di Wilayah Kabupaten Boyolali.

c. Mendorong terwujudnya Hubungan Industrial yang harmonis, serasi dan berkeadilan melalui pemantauan pembayaran UMK.

Berikut ini adalah hasil monitoring UMK yang dilakukan oleh Dinkopnaker Kabupaten Boyolali beberapa tahun terakhir:

a. Berdasarkan Pemantauan UMK Boyolali Tahun 2015 (Dinsosnakertrans Kabupaten Boyolali, Laporan Pelaksanaan Kegiatan Pemantauan UMK Boyolali Tahun 2015, Maret 2015), jumlah sampel perusahaan yang dilakukan pemantauan adalah 
sebanyak 68 perusahaan terdiri dari 27 perusahaan besar, 16 perusahaan menengah dan 25 perusahaan kecil. Perusahaan yang sudah membayar upah sesuai dengan ketentuan UMK Boyolali Tahun 2015 sebanyak 54 perusahaan $(79,5 \%)$, dan perusahaan yang belum membayar upah sesuai dengan ketentuan UMK Boyolali Tahun 2015 sebanyak 14 perusahaan (20,5\%). Masih terdapat perusahaan yang belum membayar ketentuan UMK sesuai dengan SK Gubernur Jawa Tengah Nomor: 560/85 Tahun 2014 atau membayar upah dibawah ketentuan UMK Boyolali Tahun 2015 disebabkan oleh beberapa faktor antara lain kondisi usaha perusahaan yang belum mampu; perusahan kategori industri kecil rumahan; dan sebagian dari tingkat kepatuhan pengusaha yang kurang serta terdapat sebagian pekerja yang ditetapkan sebagai tenaga kerja harian.

b. Berdasarkan Monitoring UMK Boyolali Tahun 2016 (Dinsosnakertrans Kabupaten Boyolali, Laporan Pelaksanaan Kegiatan Monitoring UMK Boyolali Tahun 2016, 15 Maret 2016), jumlah sampel perusahaan yang dilakukan pemantauan adalah sebanyak 66 perusahaan terdiri dari 42 perusahaan besar, 13 perusahaan menengah dan 11 perusahaan kecil. Terdapat dua perusahaan yang tidak beroperasi dikarenakan perusahaan tutup dan pindah ke kabupaten Sukoharjo dan tidak melapor ke Dinsosnakertrans Kabupaten Boyolali. Perusahaan yang sudah membayar upah sesuai dengan ketentuan UMK Boyolali Tahun 2016 sebanyak 36 perusahaan $(55,55 \%)$, dan perusahaan yang belum membayar upah sesuai dengan ketentuan UMK Boyolali Tahun 2016 sebanyak 30 perusahaan $(45,55 \%)$. Masih terdapat perusahaan yang belum membayar ketentuan UMK Boyolali sesuai dengan Keputusan Gubernur Jawa Tengah Nomor: 560/66 Tahun 2015 atau membayar upah dibawah ketentuan UMK Boyolali Tahun 2016 disebabkan oleh beberapa faktor antara lain kondisi perusahaan yang belum mampu karena perusahaan dalam kategori industri kecil rumahan; beberapa perusahaan kurang mematuhi peraturan perundang-undangan yang berlaku dimana perusahaan membayar upah pokok dan tunjangan tetap dibawah ketentuan dari Keputusan Gubernur Jawa Tengah tersebut; besaran UMK ditentukan sendiri oleh perusahaan; siklus pembayaran upah di akhir Desember dan awal Januari sehingga upah yang diterima menjadi lebih kecil dari UMK Boyolali Tahun 2016.

c. Berdasarkan Monitoring UMK Boyolali Tahun 2017 (Dinkopnaker Kabupaten Boyolali, Laporan Pelaksanaan Kegiatan Pemantauan UMK Boyolali Tahun 2017, 2 Maret 2017), jumlah sampel perusahaan yang dilakukan pemantauan adalah sebanyak 72 perusahaan terdiri dari 45 perusahaan besar, 12 perusahaan menengah dan 15 perusahaan kecil. Perusahaan yang sudah membayar upah sesuai dengan ketentuan UMK Boyolali Tahun 2017 sebanyak 59 perusahaan $(81,94 \%)$. Sebagain kecil diantara 59 Perusahaan tersebut memberikan upah lebih baik dari besaran UMK Boyolali tahun 2017 dengan memberikan tunjangantunjangan tidak tetap lainnya. Perusahaan yang belum membayar upah sesuai dengan ketentuan UMK Boyolali Tahun 2017 sebanyak 
13 perusahaan $(18,04 \%)$. Masih terdapat perusahaan yang belum membayar ketentuan UMK Boyolali sesuai dengan Keputusan Gubernur Jawa Tengah Nomor: 560/50 Tahun 2016 atau membayar upah dibawah ketentuan UMK Boyolali Tahun 2017 disebabkan oleh beberapa faktor antara lain sebagain kecil perusahaan keliru dalam menetapkan pembayaran upah minimumnya, sesuai dengan Undang-Undang No. 13 Tahun 2003 tentang Ketenagakerjaan dan Peraturan Pemerintah No. 78 Tahun 2015 tentang Pengupahan, yaitu komponen gaji harus dibayarkan paling sedikit sebesar 75\% dari UMK dan $25 \%$ dari UMK berupa tunjangan tetap atau ditambah tunjangan tidak tetap lainnya; beberapa perusahaan besar justru keliru dalam menerapkan peraturan perusahaannya, manakala melakukan pemotongan upah atau gaji karyawan karena tidak masuk kerja yaitu diperhitungkan sesuai dengan jumlah hari kalender sebanyak 30 hari sehingga pekerja/buruh berpotensi dapat dirugikan upahnya; belum disusunnya struktur skala upah bagi pekerja/buruh/karyawan sesuai Undang-Undang RI No. 13 Tahun 2003 tentang Ketenagakerjaan dan Peraturan Pemerintah RI No. 78 Tahun 2015 tentang Pengupahan serta Keputusan Menteri Tenaga Kerja dan Transmigrasi RI No. 49 Tahun 2004 tentang Ketentuan Struktur dan Skala Upah sehingga besaran UMK setiap tahun menjadi upah standar bagi seluruh pekerja meskipun bekerja di atas 12 bulan; terdapat berberapa pengusaha yang berkategori industri kecil, masih tidak memenuhi upah minimumnya sesuai ketentuan yang ditetapkan oleh pemerintah sehingga berdampak negatif pada hubungan industrial di perusahaan yang bersangkutan dan kesejahteraan pekerja tidak terpenuhi.

Berdasarkan Laporan Monitoring beberapa tahun terakhir yang dilakuan Pemerintah Kabupaten Boyolali cq. Dinas Koperasi dan Tenaga Kerja Kabupaten Boyolali (dahulu bernama Dinas Sosial Tenaga Kerja dan Transmigrasi Kabupaten Boyolali), dapat dilihat bahwa tahun 2015 perusahaan yang telah membayar sesuai UMK sebesar 79,5\%, sedangkan pada tahun 2016 mengalami penurunan menjadi sebesar 55,55\%, dan pada tahun 2017 mengalami kenaikan menjadi sebasar $81,94 \%$. Prosentase perusahaan yang membayar UMK Boyolali pada tahun 2017 lebih besar dari pada tahun 2016 karena kenaikan upah minimum tahun 2017 lebih sedikit dibandingkan dengan tahun sebelumnya. Tahun 2016 mengalami kenaikan sebesar Rp. 205.700,- yaitu dari Rp. 1.197.800,- menjadi Rp. 1.403.500,-Sedangkan untuk tahun 2017 mengalami kenaikan sebesar Rp. 115.789,- yaitu dari Rp. 1.403.500,- menjadi Rp. 1.519.289,. Sehingga pada tahun 2017 banyak perusahaan yang mampu membayar pekerja/buruh sesuai Upah Minimum karena kenaikan upah minimum yang tidak terlalu tinggi.

Dengan mengadopsi gambaran bekerjanya hukum dari Chambliss dan Seidman, maka bekerjanya hukum mengenai UMK Boyolali terhadap pekerja/ buruh termasuk didalamnya peranan lembaga pengawasan ketenagakerjaan, dapat digambarkan sebagai berikut:

Penjelasan:

1. Pasal 90 ayat 1 Undang-Undang RI No. 13 Tahun 2003 tentang Ketenagakerjaan, bahwa pengusaha dilarang membayar upah lebih rendah dari upah minimum yang ditetapkan oleh Gubernur. Pengusaha 
wajib membayar upah pekerja/buruh dengan masa kerja dibawah satu tahun sesuai dengan ketentuan Upah Minimum. Gubernur Jawa Tengah menetapkan besarnya upah minimum dengan mengeluarkan Keputusan Gubernur Jawa Tengah No. 560/50 Tahun 2016 tentang Upah Minimum pada 35 (tiga puluh lima) Kabupaten/ Kota di Provinsi Jawa Tengah Tahun 2017, besarnya UMK Boyolali adalah Rp. 1.519.289,- dan berlaku bagi Pekerja/buruh dengan masa kerja dibawah satu tahun. Sedangakan upah bagi pekerja/buruh dengan masa kerja satu tahun atau diatas satu tahun berdasarkan kesepakatan antara pekerja/buruh dengan pengusaha secara bipatrit dengan mempetimbangkan produktivitas dan kemampuan perusahaan dan tidak boleh lebih rendah dari upah minimum yang telah ditetapkan.

2. Implementasi UMK Boyolali tahun 2017 dan tahun-tahun sebelumnya menunjukkan bahwa masih terdapat Pengusaha yang belum membayar upah pekerja/buruh sesuai dengan UMK Boyolali termasuk usaha dalam bidang tekstil. Berdasarkan hasil monitoring Dinas Koperasi dan Tenaga Kerja Kabupaten Boyolali pada tahun 2015 perusahaan yang membayar upah tidak sesuai dengan UMK Boyolali sebesar 20,5\%, sedangkan tahun 2017 naik menjadi 45,45\% dan pada tahun 2017 turun menjadi $18,04 \%$. Hasil tersebut diperoleh dari monitoring dengan mengabil sempel beberapa perusahaan di Kabupaten Boyolali dan dilaksanakan secara rutin setiap awal tahun gaji pertama pekerja/buruh diterima. Monitoring upah minimum yang dilakukan Dinas Koperasi dan Tenaga Kerja Kabupaten Boyolali difokuskan kepada usaha yang telah terdaftar dan usaha dengan pengelolaan yang baik dengan keuangan yang stabil. Sehingga usaha-usaha kecil dan menengah yang belum terdaftar atau belum mempunyai pengelolaan yang baik dimungkinkan tidak tersentuh monitoring dinas tersebut. Seperti pada usaha konveksi CV. Triabadi Apparel yang merupakan usaha kecil yang belum terdaftar dan akan mendaftarpada tahun 2017 yang belum memberikan upah sesuai dengan upah minimum yang ditetapkan Gubernur sebesar Rp. 1.519.289,-. Berbagai alasan yang digunakan pengusaha seperti usaha masih kecil, pesanan yang belum stabil, kurangnya modal pada usaha kecil dan menengah, dan lain-lain sehingga perusahaan belum mampu membayar sesuai dengan upah minimum yang telah ditetapkan. Keberadaan usaha kecil dan menengah di Kabupaten Boyolali sebenarnya sangat membantu warga yang tinggal disekitar usaha kecil dan menengah tersebut karena mereka dapat bekerja pada usaha tersebut walaupun dengan gaji di bawah upah minimum, mereka beranggapan bahwa dengan bekerja walaupun upah masih di bawah upah minimum tetapi dapat membantu keuangan keluarga dan dapat mencukupi kebutuhan hidup. Sehingga peran usaha kecil dan menengah salah satunya adalah mengurangi angka pengangguran di wilayah Boyolali. Pada posisi Pekerja/buruh sendiri terkadang juga bersedia menerima upah berapa pun yang diberikan oleh pengusaha yang penting mendapatkan penghasilan untuk mencukupi kebutuhan hidupnya. Faktor pendidikan juga menjadi salah satu alasan pekerja/ buruh menerima berapapun upah yang 
diberikan pengusaha. Ketidaktahuan pekerja/buruh akan hak-haknya juga menghambat optimalisasi implementasi dari UMK Boyolali. Menurut Hamonang (2015: 38) bahwa setiap pembayaran di bawah upah minimum yang ditetapkan akan bertentangan dengan pasal 90 ayat (1) Undang-Undang RI No. 13 Tahun 2003 tentang Ketenagakerjaan. Pada prinsipnya pembayaran upah minimum oleh pengusaha adalah harus dan tidak dapat dikurangi. Pelanggaran terhadap ketentuan tersebut merupakan tindak pidana yang diancam denga pidana penjara paling singkat 1 (satu) tahun dan paling lama 4 (empat) tahun dan/atau denda paling sedikit Rp. 100.000.000,(seratus juta rupiah) dan paling tinggi Rp. 400.000.000,- (empat ratus juta rupiah) yang diatur pada pasal 185 ayat (1) Undang-Undang RI No. 13 Tahun 2003 tentang Ketenagakerjaan. Namun sanksi tersebut belum dapat terlaksana pada usaha kecil dan menengah seperti pada usaha konveksi di kabupaten boyolali karena kemampuan perusahaan yang memang belum mampu dan usaha kecil dan menengah termasuk kedalam program pemerintah yang merupakan usaha yang wajib dikembangkan sehingga dapat menciptakan lapangan pekerjaan yang lebih banyak dan dapat mengurangi pengangguran.

3. Pengawasan ketenagakerjaan berdasarkan Lampiran UndangUndang RI No. 23 Tahun 2014 tentang Pemerintahan Daerah menjadi urusan pemerintahan konkuren dan menjadi wewenang pemerintahan Provinsi yaitu berwenang mengawasi dan menegakkan pelaksanaan peraturan perundang-undangan dibidang ketenagakerjaan. Sedangkan wewenang pemerintah kabupaten/ kota dalam bidang tenaga kerja hanya berkaitan dengan hubungan industrial dan penempatan tenaga kerja. Pemerintah Provinsi Jawa Tengah memegang wewenang untuk mengawasi jalannya normanorma hukum ketenagakerjaan, sedangkan Pemerintah Kabupaten/ Kota Boyolali berwenang untuk memberikan pembinaan, penyuluhan, menjaga hubungan industrial, meyiapkan pengupahan dan mediasi menurut peraturan perundangundangan ketenagakerjaan dan tidak bersifat menegakkan tetapi lebih kepada menjaga hubungan Tripatrit (pemerintah, pengusaha, pekerja/ buruh). Pemerintah Kabupaten Boyolali cq Dinas Koperasi dan Tenaga Kerja Bidang Hubungan Industrial dan Jaminan Sosial Tenaga Kerja hanya melaksankan tugas pelayanan teknis dan administrasi dibidang hubungan industrial dan penerapan norma perlindungan Jaminan Sosial Tenaga Kerja. Pemerintah Kabupaten Boyolali cq. Dinas Koperasi dan Tenaga Kerja Kabupaten Boyolali hanya berwenang melakukan pembinaan dan sosialisasi terhadap impelementasi UMK Boyolali dengan melakukan monitoring setiap akhir bulan januari atau awal bulan februari serta setiap kegiatan di Kabupaten Boyolali. Semakin jauhnya pengawasan ketenagakerjaan dimungkinkan banyak pelanggaran yang terjadi di Kabupaten Boyolali. Semisal terjadi konflik antara pekerja/buruh dengan pengusaha yang membahayakan kondisi tempat kerja maka dibutuhkan penanganan yang cepat untuk meredakan konflik tersebut. Sehingga dibutuhkan pengawas 
ketenagakerjaan yang berada lebih dekat untuk menyelesaikan konflik tersebut. Dinas Koperasi dan Tenaga Kerja Kabupaten Boyolali dalam melaksanakan pemantauan upah minimum kabupaten boyolali apabila terjadi pelanggaran mengenai pelaksanaan ketentuan UMK Boyolali yang dilakukan oleh penguasha, dinas hanya memberikan pembinaan dan himbauan selanjutnya tegantung pada itikad baik pengusaha apakah mau melaksankan atau tidak himbauan tersebut. Dinas Koperasi dan Tenaga Kerja Kabupaten Boyolali hanya memberikan rekomendasi kepada pengawas ketenagakerjaan provinsi apabila terjadi pelanggaran. Sehingga pengawas ketenagakerjaan provinsi yang akan bertindak menegakkan norma hukum ketenagakerjaan tersebut.

4. Gubernur dalam menetapkan besarnya Upah Minimum tidak hanya memperhatikan salah satu pihak saja tetapi semua pihak yang terkait juga harus diperhatikan baik pekerja/buruh maupun pengusaha. Gubernur Jawa Tengah menetapkan upah minimum kabupaten dengan memperhatikan rekomendasi Bupati/ Walikota serta saran dan pertimbangan dewan pengupahan provinsi. Upah minimum yang telah ditetapkan harus diimplementasikan untuk mengetahui bagaimana berlakunya upah minimum sehingga apabila belum dapat berjalan secara optimal maka Gubernur perlu melakukan evaluasi terhadap Implementasi UMK Boyolali tersebut baik dari sisi peraturannya, pengawasannya, pekerja/buruh maupun pengusaha. Gubernur juga berwenang untuk menyetujui penanggugan upah minimum bagi pengusaha yang belum mampu melaksanakan upah minimum yang telah ditetapkan. Tetapi penangguhan tidak menghilangkan hak pekerja/buruh akan pemenuhan upah minimum yang belum dibayar pengusaha selama penanggugahan.

\section{Simpulan}

Implementasi UMK Boyolali terhadap pekerja/buruh pada usaha konveksi belum berjalan secara optimal karena masih terdapat usaha konveksi yang belum melaksanakan ketentuan upah minimum. Seperti pada Usaha Konveksi CV Triabadi Apparel yang belum menerapkan upah minimum pada pekerja/ buruh dikarenakan usaha yang baru berdiri dan pengelolaan usaha yang belum stabil serta pemberian upah berdasarkan kemampuan perusahaan dan keterampilan pekerja/buruh. Berbeda dengan Usaha Konveksi Pasifik Garment yang telah menerapkan upah sesuai dengan ketentuan upah minimum karena usaha sudah berdiri lama dan pengelolaan usaha sudah stabil dan cukup baik.

Implementasi UMK Boyolali juga dapat dilihat dari hasil monitoring yang dilakukan oleh Dinas Koperasi dan Tenaga Kerja Kabupaten Boyolali (dahulu bernama Dinas Sosial Tenaga Kerja dan Transmigrasi Kabupaten Boyolali) setiap awal tahun yaitu akhir bulan Januari atau awal bulan Februari. Hasil monitoring yang dilakukan di Kabupaten Boyolali selama beberapa tahun terakhir ini menunjukan bahwa implementasi upah minimum di Kabupaten Boyolali masih belum optimal karena masih terdapat pengusaha yang belum membayar upah sesuai dengan ketentuan upah minimum. Sehingga jaminan kesejahteraan pekerja/buruh terkait dengan pengupahan belum dapat terpenuhi secara menyeluruh di Kabupaten Boyolali. 


\section{E. Saran}

Pemerintah Kabupaten Boyolali cq. Dinas Koperasi dan Tenaga Kerja Kabupaten Boyolali seyogyanya meningkatkan frekuensi sosialisasi terkait dengan hak dan kewajiban dalam hubungan kerja baik untuk pengusaha maupun untuk pekerja/buruh, lebih sering melakukan pemantauan/monitoring terhadap pelaksanaan upah minimum seperti dilakukan setiap bulan, serta Pemerintah Kabupaten Boyolali cq. Dinas Koperasi dan Tenaga Kerja Kabupaten Boyolali diharapkan lebih aktif bekerja sama dengan Pengawas Ketenagakerjaan Provinsi dalam melakukan pembinaan dan menegakkan norma-norma hukum ketenagakerjaan.

\section{F Daftar Pustaka}

Agus Partono. 2017. Laporan Pelaksanaan Kegiatan Pemantauan Upah Minimum Kabupaten (UMK) Kabupaten Boyolali Tahun 2017. Boyolali: Dinkopnaker Kabupaten Boyolali.

Amiruddin dan Zainal Asuikin. 2004. Pengantar Metode Penelitian Hukum. Jakarta: PT RajaGrafindo Persada.

Beni Ahmad Saebani. 2009. Metode Penelitian Hukum. Bandung: Pustaka Setia.

Budi Winarno. 2013. Kebijakan Publik(Teori, Proses, dan Studi Kasus). Yogyakarta: CAPS (Center of Academic Publishing Service).

Endut A. Ini UMK 35 Kabupaten Kota di Jawa Tengah Tahun2017. http://www. jambur.com/ekonomi/20161121/3747/ ini-umk-35-kabupaten-kota-di-jawatengah-tahun-2017, diakses 4 April 2017 jam 11.42 WIB.

Hukum Online.com. Putusan MK ini kabar baik buat pekerja. http://m.hukumonline. $\mathrm{com} /$ berita/baca/putusan-mk-ini-kabar- baik-buat pekerja, diakses 23 Februari 2017 jam 21.03 WIB.

Kompasiana. Indikator Kesejahteraan. http://m. kompasiana.com/icai/indikator-kesej ahteraan_54ff1feda333112e4550f95f, diakses 2 November 2016 jam 14.00 WIB.

Lalu Husni. 2014. Pengantar Hukum Ketenagakerjaan Edisi Revisi. Jakarta: PT RajaGrafindo Persada.

Muntoha. 2009. "Demokrasi dan Negara Hukum”. Jurnal Hukum. Vol. 16 No. 3.

Pos Sore Aktual dan Kasual. Sentralisasi Pengawas Ketenagakerjaan Mulai Berlaku Oktober 2016. http:// possore.com/2016/05/09/sentralisasipengawasan-ketenagakerjaan-mulaiberlaku-oktober-2016/, diakses 4 April 2017 jam 11.30 WIB.

Purwanto. 2015. Laporan Pelaksanaan Kegiatan Pemantauan UMK Kabupaten Boyolali Tahun 2015. Boyolali: Dinsosnakertrans Kabupaten Boyolali.

Purwanto. 2016. Laporan Pelaksanaan Kegiatan Monitoring Upah Minimum Kabupaten Boyolali (UMK) Tahun 2016. Boyolali: Dinsosnakertrans Kabupaten Boyolali.

Sobardo Hamonangan. 2015. "Urgency of Legal Protection for Labor Rights within Waging Sector”. Journal of Law Policy and Globalization. Vol. 40.

Wikipedia. Kabupaten Boyolali. https:// id.m.wikipedia.org/wiki/Kabupaten Boyolali, diakses 10 Oktober 2016 jam 20.10 WIB.

Yunus Shamad. 1992. Pengupahan Pedoman Bagi Pengelola Sumber Daya Manusia. Jakarta: Bina Sumber Daya Manusia. 